\title{
Meaning in the Face of Death: Implications for Existential Counseling
}

Andre Marseille

Department of Psychology, Chicago State University, United States.

\author{
Article Details \\ Article Type: Research Article \\ Received date: $04^{\text {th }}$ June, 2021 \\ Accepted date: $14^{\text {th }}$ July, 2021 \\ Published date: $16^{\text {th }}$ July, 2021
}

*Corresponding Author: Andre Marseille, Department of Psychology, Chicago State University, United States. E-mail: amarse20@,csu.edu

Citation: Marseille, A. (2021). Meaning in the face of Death: Implications for existential counseling. J Ment Health Soc Behav 3(2):145. https://doi.org/10.33790/jmhsb1100145

Copyright: (C2021, This is an open-access article distributed under the terms of the Creative Commons Attribution License $\underline{4.0}$, which permits unrestricted use, distribution, and reproduction in any medium, provided the original author and source are credited.

\section{Introduction}

In the last three years, I lost my father, uncle and mentor, perhaps the three most important men in my life. Though I was saddened by their departure, I accept that death is part of the life cycle and that life is a series of linear 'tick-tocs' towards an inevitable death. I have grown comfortable with that. I owe this understanding and comfort to my 18-year relationship with my recently departed mentor Dr. Clemmont Vontress, the father of cross-cultural counseling and an existentialist. As I mourn his passing, I am reminded that death is a reminder of our need to make the most of our fragile existence. Frankl reasoned that accepting death was a natural part of the life cycle and that one should find meaning in their existence with the finite time they do have. It is this view which makes a person fundamentally questioned by life itself. Frankl [1] called this view a "Copernican turn."

"It is life itself that asks questions of man. It is not up to man to question; rather he should recognize that he is questioned, questioned by life; he has to respond by being responsible; and he can answer to life only by answering for his life." [2], (p. 62 )

The Copernican turn suggest that humans must be proactive and intentional in their existence because existence does not stop for them to question it. Heidegger intimates this sensibility about life with his view on death arguing that the certainty of death as 'yet-to-come' is the thing that is existentially significant rather than the biological process of death itself. Should we accept human existence from the perspective that death is inevitable, then existence is essentially but not simplistically, a constant movement toward it. This is what Heidegger [3] refers to as 'Being-towards-death.'

This essay is a personal and philosophical reflection designed to inform practice with clients facing two distinct existential issues:

1. What are the pillars of living a life full of meaning and purpose?

2. How does death motivate us to create a life with meaning and purpose?

When faced with the inevitability of death, it has been my experience that people tend strip away all the minutia of life and focus on six things: becoming, experience, meaning, authenticity, forgiveness and legacy. I refer to them as pillars of living. I have heard these sentiments echoed many different ways by many professionals in the medical field who contend with life and death every day. Over the last few years, I have given these pillars of living much thought. And as I process my own father, uncle and mentors' deaths, I have come to understand their significance in relation to our fragile existence. Hence, it is from this view, I can now see for myself, how the minutia of life can cloud the things that are most important to it, perhaps essential to it. As my father lay on his death bed, he in particular, had managed to strip away the minutia from his own life to focus on these six essential things, as he began to understand the grim inevitability of his own fate.

Even still, he made it clear; he did not want to die. He was afraid of death and he said this plainly. In those waning months, at least our conversations were more insightful. He told me he loved me constantly. He told me how proud he was that I was becoming a doctor. He told me to save money and be a good man and husband. He never called me Andre, just "my son." I realized how much of the minutia he was stripping away. The insights one can draw from death can be powerful and sobering. The remainder of this essay outlines those insights which are a product of my reflections about my father, uncle and mentor, their lives life and their deaths and what perhaps matters most in existence. To that end, I discuss six distinct and wholesomely existential and interrelated pillars that traverse life from inception to its' inevitable end -becoming, experience, meaning, authenticity, forgiveness and legacy, and what implications they have for mental health professionals working with clients who almost always face existential challenges in life. I start my reflections by discussing the significance of death.

\section{Death}

- "If I take death into my life, acknowledge it, and face it squarely, I will free myself from the anxiety of death and the pettiness of life - and only then will I be free to become myself" [3].

Vontress, Johnson \& Epp [4] defines death as the cessation of experience. In the United States, there is an aversion to dealing with death to the point of repression [5]. Vontress [4] writes that people who accept death as part of life are more courageous than those who deny it. He further writes that without death, life would have no meaning for it pushes us toward intent, toward intensity, toward purpose. So, for me, I do not want to process my father, uncle, and mentor's deaths from the lens of religion or any other orientation that threatens to take away any real meaning from the reality of their passing. I want to deal with their deaths in a manner that is meaningful, that is empowering and healing and ultimately allows me to move forward with life in a better and more thoughtful way. I want to accept their deaths, not as some benevolent or cosmic master plan with secrets yet to be revealed to me, but as a difficult part of a symbiotic life cycle that, in truth and by evidence, is and appears to be 'thee' major transition of life.

I can be shocked and saddened by my father, uncles and mentors' death because that is natural to do when you love others as I have loved them. Love is this space requires sadness naturally. However, 
I do not want to be confused about their deaths and helpless to understand that confusion, especially since I choose to carry the burden of my freedom and desire to create meaning in my own life. Sartre [6] said, "If man is nothing but that which he makes of himself," (p.28) than I must believe that "my freedom is my essence and my salvation; and I cannot lose it without ceasing to be" [7]. Anything less, and I would be running from who I am, what I believe and most importantly, any real meaning I can glean from my father, uncle and mentor's deaths.

In the face of death, freedom and choice can feel much less abstract. Elie Wiesel and Viktor Frankl both wrote about their deep and profound experiences in the face of death. From those experiences, they gave us some of the most profound insights into the most meaningful pillars of existence. I find that I would like to do the same for myself. 'Being-towards-death' reminds us that existence, in the most obvious form, is finite. By default, the inevitable movement towards death, or as Vontress, Johnson \& Epp [4] defines as the cessation of experience, demands of us that we find meaning in the finite time we have. Since life, is to be conscious of experience itself, according to Frankl, life ask the questions and it is not we who ask questions of life. Hence, how then, do we delineate what is or should be meaningful? How does one balance all that existentialism seems to require of us as beings with certain innate capacities that doom us to be free, to become, and to be responsible for our own lives (Sartre, 1946)[8]?

\section{Becoming} Eliot

"It is never too late to be who you might have been." - George

As an existentialist, becoming is a matter of embracing the beauty of existence through continual growth and evolution. Heidegger [3] argues that becoming is, "as far as we know, the human being is unfinished, always responsive to its world, and repeatedly carrying himself forward freshly, until death" (p.65). Vontress [4] writes that becoming is the ultimate realization of selfhood. In relation to becoming, what I have learned from their collective losses is that I am existentialist. There is a power, a certitude in that recognition.

In becoming, people must understand that "... a man is above all else, mind, consciousness that is, he is a product of history, not of nature" (Gramsci, 1929, p.13). I attribute much of the way I view life to a well-balanced respect for old traditions and modern beliefs. Antonio Gramsci also said, 'the point of modernity is to live a life without illusions while not becoming disillusioned," (1929, p.12). I think that is essential to any process of change and growth. To some, it is strange to think one may think of philosophy rather than spirituality when the death of a loved one happens. Yet, at the epicenter between the two -philosophy and spirituality, I am not sure I see a real difference or that there should necessarily need to be.

"Man is condemned to be free" [6], (p.5). They are free to become that which they choose because they did not create themselves. Yet still born into existence, they are responsible for everything they do. In theory, there is an indefatigable truth to this notion. However, history has shown us that freedom and becoming often are antithetical. Through the centuries, kingdoms, empires, and governments have consistently hindered the process of becoming by creating insufferable conditions in the name of freedom. The insatiable need for socially constructed rules of living based on apathetic and selfish ideals that have alienated humans from nature, insight and modernity. History has also shown how human nature unchecked has often belittled the value of human life. It has also left people with nothing more than vague explanations and promises of an existence beyond what nature has already revealed to us from the beginning; that with life comes death and with death and there is much about the fragile nature of life to hold precious.
Some of the worst canons of interpersonal living - meaning they have turned freedom into something much less inalienable - have been isms like: racism; sexism; and classism. Becoming is quite difficult under these circumstances. For instances, racism, or the belief in the superiority of another human being over another based on genetic expression, has been canonized in biblical references and other sacred documents that remain the bedrocks of both traditional and modern civilizations. How can a black person be free to become that which they feel compelled to be when America's constitution deems them $3 / 5$ human or per the 13th amendment, a slave should they be incarcerated for any reason ? How can black people be free to become when the Book of Mormon canonizes the notion that they have been cursed by nature ? In the name of religion or racism, maybe half the worlds' population, past and present, have lived and died with the burden of these misguided canons simply because some humans have darker skin than others.

Psychologically, human's innate sense of their inalienable freedom has been tainted so deeply by these socially constructed canons of living that many descendants of Africa are in conflict with their own psyche and sense of identity, stalling their own ability to become. The anguish of dealing with a 'double consciousness,' is quite a vexing existential crisis for African descendants in America and Africa. In America, Dubois argued (1969) of African Americans, "One ever feels his two-ness, an American, a Negro; two souls, two thoughts, two irreconcilable strivings." (pg. 45). In other words, one could argue as I do here, that racism has aggravated humanity's progress toward becoming, finding meaning in life, peace and prosperity. There is no better example of this than the tragedy of Black Wallstreet. Worst, it has rendered the notion that "simply being human" is inadequate.

All these thoughts are at the heart of my current state of selfexamination as I attempt to become something more than my conventional circumstances suggest. My mentors' death brought me to a sort of existential crossroad. Would I lean on the religion and faith of my education, family and culture, which says to take refuge in God's promise of eternal after life and peace, or do I lean on more existential principles, that death is a part of life and we cannot know what happens after death? What real meaning do those things give me? All this to say in relation to becoming and in good conscious, I find it exceptionally difficult, as an existentialist, would say, to be authentic, by leaning on traditions of religion and even my Haitian culture to help me find meaning about my father's and uncles' death.

Philosophers such as Soren Kierkegaard (1843/1989 )[9] and Paul Tillich [10] noted that the conceptual and the finite are not the ultimate problems, but infinity or the 'groundlessness of being' are. This reminds me of an argument posed by Gramsci that I say, somewhat acutely defines how I view and feel about the slippery slope of becoming and meaning making in life. He argues,

- "Common sense is not something rigid and stationary, but is in continuous transformation, becoming enriched with scientific notions and philosophical opinions that have entered into common circulation.' Common sense' is the folklore of philosophy and always stands midway between folklore proper (folklore as it is normally understood) and the philosophy, science, and economics of the scientists. Common sense creates the folklore of the future, a relatively rigidified phase of popular knowledge in a given time and place" (Gramsci, 1984, 420-21)

However, even in my evolution as an existentialist, I am not guaranteed total clarity or some immediate form of efficacy in this realization. Vontress never said that becoming was easy, rather it should be inevitable and we should be open to the process. As he explained to me once upon a time over lunch, one of his instances of becoming. He remarked about his own evolution of viewing culture as somewhat of a static dynamic from which people define themselves to an 
existential one where that endows humanity with the tools to create meaning and value in their lives no matter their circumstances.

As a working definition, Vontress explained to me that becoming from the view of existentialism is concerned with the exploration and understanding of a person's orientation to the world, to themselves, and what it means to be alive. And in that understanding there is always more to be uncovered. Yet, existentialisms' rich heritage of examining the meaning of life has also provided some broad latitude of interpretation. For example, European existential thought like those of Kierkegaard and Nietzsche, emphasized 'the mystery of being' (Burston \& Frie, 2006). This perspective focused on the struggle and adventure of a meaningful existence. On the other hand, Eastern existential thought like Buddhism and Taoism, emphasize the 'harmony' of being,' or the acceptance and equanimity of meaningful existence (Schneider \& Tong, 2009). Hence, becoming is a long and difficult process of self-knowledge, courage and authenticity.

\section{Experience}

Death is a cessation of experience and life is an awareness of experience. The self emerges through experience [11, Sartre, 1956). My experiences have taught me a great deal about existence. Perhaps Sapir [12], argues that, "the true locus of culture is in the interactions of specific individuals" and "in the world of meanings which each one of these individuals may unconsciously abstract for himself from his participation in these interactions" (p.515). This observation explicates the cosmic connection between culture, experience and meaning making. Following this logic, culture becomes, at the very least, the obvious canvass from which one can choose to examine our lives.

Dewey [13] writes about the existential nature of experience while emphasizing the impact of culture saying,

- "Experience is not a rigid and closed thing; it is alive and therefore grows. When dominated by past, custom, routine, it often opposes what is reasonable, what is thought. But experience also includes reflection, which frees us from the surrounding influence of the senses, the appetites, the tradition. Thus, it becomes able to accept and assimilate everything that the most exacting and penetrating thought discovers." [13] (p. 199) .

Experience in relation to culture implies meaning must have context. In philosophical terms, this is referred to historicity. Historicity or as some call it, historical consciousness, is the historical awareness that recognizes the whole range of time orientation. Further, it recognizes the forms of human awareness of being and becoming in time. Wilhelm Dilthey (1911) explains that historicity identifies human beings as unique and concrete historical beings. For Binswanger [14], specifically, he argued that meaning was derived from a person's experiences of fundamentally immersing themselves into a world of human relating. By immersing oneself into the world, that also includes the immersion of temporal relatedness that gives way to establishing an historical awareness of being. According to Binswanger [14], experiences are drawn from the world within three interrelated domains of existence comprising the Umwelt (or physical dimension), the Mitwelt (or social dimension), the Eigenwelt (or psychological or inner dimension). Later, Emmy van Deurzen-Smith (1988) added another dimension - the Uberwelt (or spiritual dimension) to account for the spiritual dimension that many existential philosophers, including Jaspers, Heidegger, Tillich, Buber and Marcel often opined.

Perhaps the most utilized approach in existentialism, phenomenology is literally the sustained study of experiences "the things themselves" without metaphysical and theoretical speculations [15]. In phenomenology, there is a distinction about the meaning drawn from the most significant contributor to experience is culture. Edward

different experiences. Experiences are essential to existence yet they are vastly different in their degree of meaningfulness to a person. Experience culminates both appearance and essence, or rather between the ordinary things within our experiences and what experiences ground and guide experience [16]. Both are experienced, yet appearances are mundane and typically without substance while essences are those experiences people have that ground them and give them a sense of direction, meaning and value to their lives. Sartre (1927) most known for his argument that existence precedes essence, explained that the central concern for a person is that they are in fact, unique beings - independently acting and responsible, and conscious ("existence"). They are not merely labels, categories, a series of demographic data they neatly fit into ("essence"). The actual life of a person is what constitutes their "true essence [17].

Historicity and culture outline experience, create facticity and fuels meaning making. Thus, it is up to each of us to discern what is meaningful from our experiences and how those experiences give us meaning. For me, I had several meaningful experiences with my father, my uncle and my mentor. In reflection, I differ from Aristotle's understanding of essence as something in-itself, which cannot be otherwise. I think what is in-itself (essence) depends on the relative experiences (existence), of the person, hence, it is always otherwise. This understanding of the dynamic between essence and existence is the undercurrent of becoming and because this is so, essence and existence are symbiotic. For the person to become, they must learn from both.

Hence, those experiences, perceived as an essence or rather, an essentiality to my existence, has anchored my way of thinking about existence in between the vast spectrum of existence and the inevitability of death. Perhaps most notable of these experiences for me was Vontress' wise words to me about placing an emphasis on creating harmony in my existence by understanding not only that death is a part of life, but becoming always gives one a chance to create or recreate a purposeful existence. He also said creating and sustaining harmony and rapport among ones' mitwelt, eigenwelt and umwelt is the key to having the most fulfilling experiences. We must respect people, nature and ourselves to make the most of experience, to clear the pathway to authenticity, meaning and legacy building. In other words, we must establish respect, harmony and rapport across all dimensions of existence [4].

\section{Meaning}

Perhaps the most central issue facing me in light of the deaths of my father, uncle and mentor is, what should their deaths mean to me? To be sad or remorseful and such is not enough. Frankl argued that living for any period of life, without there being a sense of meaning, produces an existential crisis or "existential vacuum" (Frankl 1963, p. 167f), or a life without much meaning. To that end, Frankl's form of therapy focused on the discovery of meaning(s) and orienting patients toward the future. Troubled by Freud's' insistence of the libido as a primary motivation for existence, Frankl often contrasted his "Logo Therapy's" primary motivation, the "will to meaning", with the psychodynamics of Freud's "will to pleasure" and Adler's "will to power" (Frankl, 1963, p. 154; 1988, VII f).

Vontress, like Frankl saw the goal of his therapy was to enlighten the patient on his or her conditions in life in order to work toward a "meaningful existence" (Frankl, 1987). In order to do so, Yalom (1980) argued that people must contend with the 'givens of existence' that lie deep in their conscious and are intrinsic properties inescapable from the human experience. For Yalom, humans seek meaning by the nature of their design and that freedom, death, aloneness, and the challenge for meaning in a meaningless universe were unavoidable. One of Dr. Vontress' most significant points about existentialism was, it is more than an orientation a therapist chooses to practice, but rather,
JMHSB, an open access journal 
the way he or she chooses to live their life. Merleau-Ponty (1962) once wrote, "we are condemned to meaning" (p.xxii). So being an existentialist as I have come to view myself, means I cannot permit receiving someone else's version of meaning but choosing how I find my own meaning, especially in such intimate matters like my father, uncle and mentor's deaths.

Many people find meaning in the death of their loved ones through religion. My Haitian culture is no different. Though existentialism has endured a bad reputation for being pre-occupied with death and despair, ironically, so has religion over the centuries (e.g., Northern Crusades, Albigensian Crusade, The Christendom Crusades, the Thirty years War). Kurt Vonnegut (1969) points out in his work, The Slaughterhouse- Five, humans in general, find comfort in believing that there is a greater meaning to everything though that is not necessarily life. In an almost insatiable way, people continue the search for meaning beyond the value of their own existence. In fairness, it is not necessarily prudent to make leaps about the impact that certain 'isms' have had on the overall human condition; but one cannot argue that many have used these isms as well as sacred texts like the Bible, Koran or Torah to justify the degradation of human life and the human spirit.

In particular, Yalom explained that death was a core existential conflict. It was the tension between the awareness of the inevitability of death and the wish to continue to be. From his famous lecture, Existentialism is a Humanism, Sartre (1946) argues "man, first-ofall, exists, encounters himself, surges up in the world - and defines himself afterwards"(p.70). This notion becomes ever more significant when attached to the inevitability of death for it sets in motion a finite amount of time where one can cultivate meaning out of their existence.

From this view, meaning comes from the periodic reflection or introspection one undertakes of their own life experiences. Meaning is derived from the insight gained about the essences of ones' cumulative life experiences. The matter of reflection or introspection in relation to meaning making is an important one. E. Stein (1989) writes, "when we empathically run into ranges of values closed to us, we become conscious of our own deficiencies or disvalues. Every comprehension of different persons can become the basis of an understanding of values" (p. 118). This comprehension augments are empathetic aptitude. Empathy, E. Stein argues along with selfknowledge is, an "important aid to self-evaluation" (Ibid). It is also a powerful antecedent of self-awareness: that which gives people the capacities to make meaning out of a world of boundless freedom and an existence that may or may not have a living God. According to Nietzsche (1844-1900), God was dead or rather, that for some people, there were a loss of collective faith in religion and traditional morality which in turn created existential crisis [18] for most. Hence, it seems to me that regardless of religion, it is incumbent upon each person, in the absence of an ultimate guider, to find meaning in life for themselves.

In existentialism, essence is the summary of one's life experiences that ground them and give them a sense of direction, purpose and value [19]. This reflective/introspective process must account for historicity, culture, freedom, self-knowledge and courage to be authentic meaning. Hence, to answer the question, "what meaning does the essence of my experiences with my father, uncle and mentors' life bring me? Or, a more practical inquiry, what meaning did their myriad talks, life lessons and mere presence teach me? To pursue these answers in isolation of the aforementioned existential themes, or in the abstract comfort of religious proverbs, or without considerations of my Haitian culture and Black history would have been misguided, inauthentic and ultimately meaningless.

Martin Heidegger has argued that authentic existence (as in the face of death) is an utterly individualized experience one cannot share with others. So is the pursuit of meaning. Moreover, Binswanger view that meaning is derived from a person fundamentally immersing themselves in a world of human relating cannot be taken lightly either. Afterall, I am reflecting upon the interpersonal connection of my father, uncle and mentor and their impact on my life or rather, my mitwelt and eigenwelt. Drawing on Heidegger's (1962) notion of being-in-the-world, Binswanger examined his patient's experiential worlds of meaning and verstehen (understanding), which he referred to as "world-designs." This view is vastly different from Kierkegaard and Nietzsche who reasoned that individual interests and communal interests are antagonistic by nature (Burston \& Frie, 2006). At times perhaps, but not by nature. In fact, these interests must convalesce in order to create real meaning, thus what would be the value of culture or Binswanger's domains of existence, if that were not the case? I feel that Binswanger had the right idea. His relational and collective notions of existence made me feel that it was altogether possible to pull from what I knew, what my senses suggested to me, what experiences I could reflect on, and what existential questions I could reason with in order to find real meaning in their deaths.

As I think about my father and what I could derive from his life to make mines more meaningful, I recalled his intelligence, his sternness, his protective nature, his resilience and manliness. My father was a well-read man who could talk about almost any subject. I recall reading an excerpt about a layman who ran into Thomas Jefferson en route to some place and they spoke for hours. He said after his encounter with Mr. Jefferson that when you spoke with him on any subject, you would have thought he was in fact, a master of that subject. Should a person mention engineering, medicine, agriculture or politics with him; Mr. Jefferson could speak as if he were that.

As I listened to my siblings and uncles and aunts talk about my dad and his time as a math professor back in Haiti, I realized that perhaps he too made people feel the way Jefferson made people feel. Perhaps that was stretching it a bit but a new and fresh pride had grabbed a hold of me. I smiled at the reverie. Was my father that intellectually ambidextrous? I could not be sure but, it certainly made me feel smart and proud. After all, it was my dad who taught me how to tie my shoes, to do math, and appreciate reading and creative writing. He was the one who helped me understand that Creole was not French and that I needed to learn both to be really understand what it meant to be Haitian. That was the essence of my experiences, and the meaning I draw from my time with my dad. The memories as well as the fresh stories about his passion for education and his intellect certainly made me feel more authentic in my being and aligned with my present academic pursuits.

\section{Authenticity}

Authenticity is a central concept in existentialism. Authenticity is originally a Greek word authentes. It means "one who act with authority" or "what is done by one's own hand" [20], (41). One's ability to recognize their existence as inevitably 'being-towardsdeath,' should persuade one to live a more authentic existence. Yet, for most of people, this is not the case. As my father slowly pass from this life, I felt his pushed toward it as he removed the ego and pride that once governed all his whims. It became clear to me that the burden of living in bad faith, as Sartre (1996) noted, overwhelmed him. As death came for him, it became much easier for my father to recognize and admit to his own fallibilities and failures in life. $\mathrm{He}$ was sorry for not being the best husband and father he could be. The regret of time wasted was etched in his face. He communicated this often, desiring more than anything for his family's forgiveness and time in his final moments.

Authenticity relates to two important concepts, freedom and facticity. Freedom, from the existentialist view, is the reality that 
one's life is boundless with possibilities to create and recreate themselves into whatever they see fit. In relation to authenticity, it is the idea that one has to "create oneself" and live in accordance with this self. As I said, this is very difficult for most people for they often desire acceptance more than genuineness. What Sartre called "bad faith," Heidegger "inauthenticity," and Jaspers "life in a shell", each articulates a type interference that canopies us from one's ability to be authentic. To live authentically, one should always act as oneself despite any external forces or pressure. However, the push and pull of society often makes living authentically quite difficult. The most authentic person I have ever met was my mentor, Dr. Vontress. He lived by very clear principles and standards. He had the courage to be himself and I admired this about him very much. He often told me that courage and self-knowledge were keys to living an authentic existence. One can always be more than what the world, their parents, their fears say they are or can be. For Vontress, born in 1929 to sharecroppers, in a time of Jim Crow, became a renowned existentialist and the "Father of Cross-Cultural Counseling." He was most certainly more than a product of his own facticity.

Facticity is a constraint and a condition of freedom. Facticity is defined by Sartre in his work Being and Nothingness (1943) as the in-itself, which describes the modalities of being and not being. This can be more easily understood in the common saying that "one is a product of their environment." However, and more importantly, facticity also implies that one is and can always be more than their past, their environment, or their circumstances. That is what freedom in existentialism truly means. One the other hand, a denial of one's concrete past constitutes an inauthentic living. Hence, facticity, in relation to authenticity, involves acting on one's actual values when choosing their path or creating meaning in their life rather than "choosing randomly" as Kierkegaard's Aesthete [21] suggest. It also involves trust in oneself and courage [4]. My experiences have been that too few people evolve past their aesthetic thus they rarely truly trust in themselves and display the courage to live by their own dictates [22].

Living authentically has significant implications for mental health. To be authentic, it requires a constant self-examination of meaning, freedom and personal accountability [4]. People who only define themselves or other people based on topical identity factors like class, religion, race, and nationality, or the facticity factors like childhood experiences and subconscious motives only, set themselves up for inauthentic living. These factors are merely illusive and spurious and distracts people from recognizing their own fragility. In existentialism, life is always about moving forward. Being authentic is accepting this premise by ensuring that each step one places in front of the other is one that is intentional, ethical and with purpose. These are relatable life principles to me. They allow me to trust myself and the decisions I make. Unlike my mentor, I'm not sure if my father allowed himself the benefit of truly engaging these principles in his life. On his death bed, I witnessed the misery it caused him in the end.

\section{Forgiveness}

Forgiveness is a multi-dimensional concept that many disciplines like political science, theology, anthropology, psychology, philosophy, and sociology has researched extensively [23]. Yet, despite the fact that the social sciences have shown more interest in the elements of forgiveness, there is no consensus on "what forgiveness is and what processes facilitate or impede the ability to forgive" [24] (p. 2) . Forgiveness is a fundamental Segway to happiness; and like other affirmative emotions such as hope, compassion, and appreciation, is a natural expression of our humanity. Since true forgiveness requires the consideration of the offense committed along with hurt, pain and shame attached to it, forgiveness is a capacity based on virtue and strength of character $[25,26]$.

\section{According to Nietzsche (1876/1997),}

"In the case of the smallest or of the greatest happiness ... it is always the same thing that makes happiness happiness: the ability to forget or, expressed in more scholarly fashion, the capacity to feel unhistorically during its duration" (p. 62).

In our ability to always respond to the world, one can become anything they desire, but first they must show to themselves and others an authentic ability to find peace with the unjustness of the world. Wade, Worthington, and Meyer [26] argue that "true" and "appropriate" forgiveness includes the ability be realistic about the offender and the offense committed and to consider the person behind the offense and acknowledging the nature of the incident holistically (i.e., good and bad. That is, the capacity to generate positive feelings such as compassion or empathy from within underpin our ability to forgive. This is why the virtue of forgiveness is central to being, harmony and interpersonal living. Forgiveness is a part of many world religions, including Christianity, Buddhism, Hinduism, Islam, and Judaism [27] as Forgiveness requires a "willingness to abandon one's right to resentment, negative judgment, and indifferent behavior" [24], (p. 3).

The significance of forgiveness in existentialism is that it echoes the same foundational principles about freedom and choice. It is also necessary to unimpeded the process of becoming. Forgiveness is not something one must due. It is an active, conscious decision that when done authentically, forces one to engage their capacities both innate and condition, for enlightened reasoning. Further, forgiveness emotionally releases some unjust experience that causes discomfort and conflict with ones' relational world. Forgiveness mitigates the suffering we feel about difficult situations. Forgiving is not forgetting but putting the essence of a negative experience in a place that does not marginalize one's ability to become. In existential theory, we are always becoming something and forgiveness allows us the ability to clear our life paths to becoming more than what our past says we should be. There are three types of forgiveness one must engage to truly benefit from it. The first for is interpersonal forgiveness for an offense against you. The second is intra-personal forgiving yourself for not living up to your own values or principles. Finally, the third form of forgiveness is existential. It is the ability to forgive that which is unfortunate yet out of one's control. It is the type of forgiveness one may experience when they lose their home to natural disasters or a random act of violence [28].

When a person feels they have been wronged, forgiveness, requires them to acknowledge the pain of the wrongdoing; to count the cost of the offending actions, and then to take up the "last of the human freedoms; to choose one's attitude in any given set of circumstances, to choose one's own way" [29]. In "The Sickness unto Death," Kierkegaard explains that the question of forgiveness as it relates to God is, is God capable of forgiving all? His quest to answer this profound question came as a result of his work examining the different forms of despair that accompany an inability to forgive. In this regard, Kierkegaard explains that forgiveness is love and God is free to love and forgive despite objection and reason.

The final conclusion to "The Sickness unto Death" is that there is nothing God cannot forgive. I mention this story because is illustrates to me, that in order to become what I intend in life, whatever that may be, then there is nothing in this earthly place that can limit that possibility except my choices. In addition, if I choose not to forgive than I must accept the possibility that I am limiting my own ability to become. For a lack of forgiveness, or inability to forgive keeps us bound by the very hurt and injustice we seek to get away from. As I watched my father slowly leave this earth, he sought forgiveness from my mother for his failures as a father and husband. Without hesitation, I watched her hold his hand and tell him she forgave him. It was one of the few moments he managed a smile. 


\section{Legacy}

"Death comes to all, but great achievements build a monument which shall endure until the sun grows cold." (Emerson, 19XX)

Often when you think about legacy, it's something that is left behind after a person has passed. However, like existentialism, legacy is at the core of not only meaning but lies at the core of human existence. The process of establishing, giving and receiving of legacies is central to human existence. What it means to be human in relation to legacy include the entire spectrum of human emotions including: hope, love, connection, regret, anxiety, fear, dread, jealousy, bitterness, rage, purposelessness, accomplishment, pride, contentment, joy, gratitude, and humility. All the attributes that have been aforementioned lead inevitably to establishing legacy.

The death of my father, uncle and mentor has shown me the importance of living to establish a legacy. It is certainly more than merely sharing what one has learned, accomplished, and acquired. Material possessions matter but it is only a small fraction of what legacy is all about. Norman Cousins [30] wrote of legacy in a provocative piece that captures the personal, altruistic and generational nature of it. I share a few excerpts that are quite salient in relation to legacy. He writes,

"What is the eternal and ultimate problem of a free society?

It is the problem of the individual who thinks that one man cannot possibly make a difference in the destiny of that society.

It is the problem of the individual who doesn't really understand the nature of a free society or what is required to make it work.

It is the problem of the individual who has no comprehension of the multiplying power of single but sovereign units...."

On his death bed, my father, talked incessantly about his children and their accomplishments. I could see the pride in his fading eyes that I would soon become a doctor. He knew he would not live to see the day I graduated, but he knew. And I knew that made him proud because he could attach himself to my accomplishments. I was proud of that too. Though we had our differences, part of his legacy would always be how much he drilled the importance of education into my mind. As for my mentor, he was more of a living legacy. His impending death was something he did not fear or runaway from. He was comfortable in knowing what he had accomplished in life and he also knew he had atoned for certain failures in his life as well.

And then there was my uncle, the funniest, most family oriented and selfless man I have ever known. He was my blood and that made me proud just to know that. His legacy is not only having two lovely and successful daughters but he will always be remembered as a man who dedicated himself to his work, his family. He would always be remembered for his generosity, patience, style and sense of humor. I think this is what Cousins meant in his poem when he wrote about individuals who have a comprehension of the multiplying power of single but sovereign units. For me, in particular, my ideas of an ideal family, how to be a head of a family will be forever set by him. I remember when I would visit him from time to time as he suffered from the same affliction that killed my father, he told me that he regretted his lack of life balance. He worked too hard because he had always reasoned that he would live his best life in retirement. Unfortunately, illness robbed him that dream. Yet his had no real regrets. His story reminds me of one of Camus [31] absurdist philosophies, the Myth of Sisyphus.

In the story, Sisyphus was punished by the gods. As a punishment, he was tasked with rolling a boulder up a hill for the rest of his days. He would painstakingly roll a large boulder up a steep hill repeatedly, only to watch it roll all the way back down. According to Camus [31], Sisyphus task were akin to the tasks people face daily in their lives. People are tasked with boulders of their own each day be it work, school, chores or caring for family members and every J Ment Health Soc Behav

Volume 3. 2021. 145 day of our lives, we repeat these tasks in a world that is meaningless and cares little for our burdens. Camus reasons it is ultimately absurd.

However, that is not the end of the story. As presented, one would think it absurd and negative. Yet, the question is ultimately about Sisyphus and his perception of his daily burden. After all, who would choose to live a Sisyphean tragedy? According to Camus, the solution is to "imagine Sisyphus happy." Thus, if we look at Sisyphus, not as the victim of a tragic fate, rather as a man who enjoys his work, despite his absurd existence; then, perhaps this is not such a negative outlook on our existence or potential lack of meaning. Essentially, we create meaning through our own experiences and our interpretations of them. My uncle, one of the funniest men I ever knew was Sisyphus. Listening to those who knew him and loved him at his funeral evidenced this to a great degree. I felt proud and humbled to know how much joy he got out of living for his family and coworkers. It taught me that happiness is not something yet to come but should be sought in the present as we live our daily lives of meaning and purpose.

Existentialism is many things. It is about the present, meaning and purpose. It is about authenticity and self-knowledge. These are all the ingredients that make up legacy. Hence, legacy is about life and living. It's about learning from the past, living in the present, and building for the future. Legacy is not singular but holistic. It is something that is fundamentally altruistic. It is an offering of oneself, whether it be for children, a partner, or society, it is about making a meaningful and lasting contribution to something greater than yourself, like my uncle did, like my mentor did. Hence, the central requirements of a legacy are that one embraces their uniqueness and passionately immerse themselves into the world to ensure that your life will better the lives of others beyond your time on earth.

\section{Implications for existential counseling}

This section feels unusual for this type of article. Yet, I realize that so many people have seemingly lost a sense of purpose and meaning in their lives since the COVID-19 pandemic started. In my work as a therapist, many of my patients suffer from a great deal of existential anxiety, and some existential crisis. In existential therapy, meaning is perhaps the most significant theme. In order to help patients, establish meaning in their lives, the existential therapist adopts a non-judgmental attitude and seeks to explore the patient's worlds, rather than imposing his or her theory onto the patient's experience. This includes core ideas of existence like religion, spirituality, life and most disconcerting, death. Death and loss have been central issues during the COVID-19 pandemic and one that has brought into perspective the fragility of life.

Hence, the implications for counseling revolves around life, death and the fragility of existence. People from all walks of life cannot escape these features of existence and the pandemic, particularly those of us who have survived it, should take a moment to understand for themselves what are the most important things in the life. For death pushes us to consider what I feel are central pillars of existence including becoming, experience, meaning, authenticity, forgiveness and legacy. As an existential therapist who has experienced the death of such beloved family and friends over the last few years, the most significant lesson I take from these experiences are that while life filled with many possibilities, what matters most is that people focus on a select few in order to create a worthwhile existence. The inevitability of death, the evolution of becoming, the rhythm of meaning, the consistency of authenticity, the empathetic courage of forgiveness and the power of legacy, all fulfill the requirements of a worthwhile existence.

Moreover, these attributes are keenly poignant in the moments leading to death. Hence, they should also be the attributes that we seek to fulfill when youth and possibilities seem infinite. People are fallible and will waste some time during their lives engaging JMHSB, an open access journal 
in things that only merit immediate gratification. This is true of all of us and perhaps what makes us most human but as an existentialist, I see it as my responsibility to help people engage these attributes to the fullest extent possible. Those who do, will find happiness as a by-product of those efforts, those who do not, more often than not, will think of these things incessantly, when death reaches their door. In therapy, we must highlight for our patient's the serene relationship to the basic conditions of life, such as death because it leads them to a freer, more open and well-rooted life.

Competing Interests: The author declares no competing interests.

\section{References}

1. Frank1, V. (1959a). From death camp to existentialism: A psychiatrist's path to a new therapy Lasch, Trans.). Boston: Beacon Press. (Original work published 1946

2. Frankl, V. E. (1973). Psychotherapy and Existentialism Selected Papers on Logotherapy_.

3. Heidegger, M. (1927/2011). Being and Time (Macquarrie, J., Robinson, E., Trans.). New York, NY: Harper \& Row

4. Vontress, C.E.,Johnson, J.A. \&Epp, L.R. (1999). Cross-cultural counseling: A casebook. Alexandria, VA: American Counseling Association.

5. Rollo. M. [1967] 1996. Psychology and the Human Dilemma. W W Norton. ISBN 0-393-31455-3

6. Sartre, J.P. (1948). Existentialism And Humanism. London England: Methuen Publishing Limited.

7. Scruton, Roger (2012). "Working toward Art". In Hamilton, Andy; Zangwill, Nick (eds.). Scruton's Aesthetics. London: Palgrave Macmillan, 1.

8. Walter, K. (1989) Existentialism from Dostoyevsky to Sartre, ed., 1946 lecture, Meridian Publishing Company

9. Saeverot, H (2011) Kierkegaard, seduction, and existential education. Studies in Philosophy and Education 30(6): 557-572.

10. Tillach, P. (1952). The Courage to Be. Second Edition. New Haven, Yale University, 2000 (1st ed. 1952). 197 pages.

11. Greene, M. (1973). Teacher as Stranger Educational Philosophy for the modern age. Wadsworth Publishing Co. Belmont California.

12. Sapir, E. (1932). Cultural anthropology and psychiatry. Journal of Abnormal and Social Psychology, 27, 229-242

13. Dewey, J. (1959). Como Pensamos. Trad. H. C. Campos, 3. ed. São Paulo: Cia. Ed. Nacional

14. Binswanger, L. (1963). Being-in-the-world. New York: Basic Books

15. Husserl, E. (1931). Ideas: general introduction to pure phenomenology. United States of America: Hackett Publishing Company, Inc.

16. Ehrich, L. C. (1999). Untangling the threads and coils of the web of phenomenology. Education Research and Perspectives, 26(2), 19-44, van Manen, M. (1997). Researching lived experience: Human science for an action sensitive pedagogy (2nd ed.). Canada: The Althouse Press.

17. Baird, F. E.; Kaufmann, W. (2008). From Plato to Derrida. Upper Saddle River, New Jersey: Pearson Prentice Hall. ISBN 0-13-158591-6.

18. Camus, A. (1950) The Rebel. Vintage Books

19. Kafle, N., P. (2011). Hermeneutic phenomenological research method simplified. Bodhi: An interdisciplinary Journal, 5(1), 181-200.
20. Resse, W.L. (1980). Dictionary of philosophy and religion. Atlantic Highlands, NJ: Humanities Press

21. Adorno, T. W. (1989). Kierkegaard: Construction of the Aesthetic, Robert Hullot-Kentor (trans.), Minneapolis: University of Minnesota Press.

22. Lowen, A. (1980). Fear of life. New York: Macmillian.

23. McCullough, M. E., Pargament, K. I., \& Thoreson, C. E. (Eds.). (2000). Forgiveness:

24. Cosgrove, L., \& Konstam, V. (2008). Forgiveness and forgetting: Clinical implications for mental health counselors. Journal of Mental Health Counseling, 30(1), 1-13.

25. Sandage, S. J., Hill, P. C., \& Vang, H. C. (2003). Toward a multicultural positive psychology: Indigenous forgiveness and among culture. The Counseling Psychologist, 31, 564-592

26. Wade, N. G., Worthington, E. L., Jr., \& Meyer, J. E. (2005). But do they work? A meta-analysis of group interventions to promote forgiveness. In E. L. Worthington, Jr. (Ed.)., Handbook of forgiveness (pp. 423-440). New York: Brunner-Routledge

27. Domino, C. (2009). The law of forgiveness. Berkley Books, New York, ISBN 10: 0425229955

28. Luskin, F. (2001). Forgive for Good: A proven prescription for health and happiness. HarperCollins, 240 pages.

29. Frankl, V. (1984). Man's search for meaning. Boston, MA: Pocket Books.

30. Cousins. N. (1974). The celebration of life: A dialogue on hope, spirit and the immortality of the soul. Bantam Books, New York

31. Camus, A. (1955). The Myth of Sisyphus and Other Essays. New York: Alfred A. Knopf. ISBN 0-679-73373-6. 